\title{
LA DOBLE NATURALEZA DE DEUDA HEREDITARIA Y ASIGNACIÓN HEREDITARIA FORZOSA DE LOS ALIMENTOS DEBIDOS POR LEY A CIERTAS PERSONAS*
}

\author{
THE DOUBLE NATURE AS HEREDITARY DEBT AND HEREDITARY \\ FORCED ASSIGNMENT OF THE ALIMONY OWN BY LAW TO \\ CERTAIN PEOPLE
}

\section{AlejAndro GuZMÁN BRITO**}

RESUMEN: El presente artículo expone la doble naturaleza que en el Código Civil ofrecen los alimentos forzosos, constituidos en vida del alimentante, después de su muerte, los cuales aparecen tanto como una asignación hereditaria forzosa, que se paga con el límite de las fuerzas de la herencia y con bienes de esta, cuanto como una deuda hereditaria. Sostiene el artículo, empero, que es más potente el carácter de deuda hereditaria. Y se afirma que al sobrevenir la muerte del que en vida estaba obligado por sentencia o transacción a prestar alimentos, no cambia la naturaleza obligacional de estos y que solo se convierten en deuda hereditaria, con ciertas especialidades y peculiaridades, sin embargo, derivadas de su carácter de asignación. Se defiende que este último carácter es una figura inane de la ley, que nada agrega al hecho de tener que pagarse la deuda alimenticia por los herederos del alimentante, no por ser asignación forzosa, sino por ser deuda, igual que todas las demás que aquel contrajo en vida. Se explica la subsistencia de la asignación forzosa como un relicto de la historia legislativa del articulado concerniente a los alimentos en los diversos proyectos de Código Civil.

Palabras clave: Asignación hereditaria de alimentos forzosos, Deudas hereditarias, Transmisibilidad de la obligación alimenticia.

ABSTRACT: This article presents the double character that the alimony set during the life of the obligor possesses according to the Civil Code after the obligor's death. In fact, the obligation remains enforceable either in its character of "asignacion hereditaria forzosa" (comparable with the statutory legathy provision), payable with and up to the limits of the estate of the deceased or in its character of "deuda hereditaria" (comparable with the hereditary debt). This article argues that the latter is much better than the former; and will show that upon the death of the obligor the character of the alimony does not change and that although it becomes a "deuda hereditaria" with certain special and peculiar aspects, it becomes so because of its original character as alimony. This article will also argue that this last character derives from the law. Further, it will also show that the alimony has to be met by the heirs of the obligor because of it character of debt, similar to all the others debts contracted by the deceased while still alive, rather than its character

\footnotetext{
* El presente trabajo hace parte del proyecto FONDECYT No 1070432/07.

** Licenciado en Ciencias Jurídicas y Sociales por la Universidad Católica de Valparaíso, Doctor en Derecho, Universidad de Navarra, España; profesor titular de Derecho romano de la Facultad de Derecho de la Pontificia Universidad Católica de Valparaíso; dirección postal: Avenida Brasil 2950, Valparaíso, Chile; correo electrónico: aguzman@ucv.cl
} 
of an "asignacion hereditaria forzosa". Finally, this article provides with a likely explanation for the subsistence of the "asignacion hereditaria forzosa", mainly the history of Civil Code and particularly the different drafts which preceded the final version of the Civil Code in relation to alimony.

Key words: Asignables hereditary food forced, Debts inherited, Transferability of the maintenance obligation.

1. El Código Civil trata de los alimentos forzosos en el título 18: De los alimentos que se deben por ley a ciertas personas, de su libro I: De las personas; y en el $\$ 1$ : De las asignaciones alimenticias que se deben a ciertas personas, del título $5^{\circ}$ de su libro III: De la sucesión por causa de muerte [...]. En la concepción de ese cuerpo legal, pues, la figura empieza a tener lugar durante la vida del alimentante y se mantiene después de su muerte bajo la forma de una asignación forzosa.

Esta secuencia plantea dos problemas. El primero consiste en determinar qué alimentos entre vivos constituyen el objeto de la asignación por causa de muerte forzosa. El segundo radica en determinar qué bienes soportan el cumplimiento de la asignación forzosa.

a) Por lo que atañe al primer problema, se presentan varias situaciones a consideración, como son: i) que un alimentante hubiera sido constituido ya entre vivos en tal calidad por sentencia judicial (y eventualmente por transacción judicialmente aprobada) y que al morir dejara algunas mensualidades alimenticias atrasadas en su pago ${ }^{1}$; ii) que un alimentante hubiera sido constituido también entre vivos en tal calidad, merced a una sentencia judicial firme o a una transacción judicialmente aprobada y que al morir no debiera mensualidades atrasadas; iii) o que, sin mediar ni la una ni la otra entonces, hubiera sido demandado, empero, por alguien que pretendía tener alguno de los títulos legales del artículo 321 CC. para pedir alimentos, y que el demandado muriera antes de ser emitida la sentencia o llegar a una transacción; iv) que alguien pagara voluntariamente alimentos en vida a otro, pero bajo el concepto de debérselos como forzosos merced al dicho artículo $321 \mathrm{CC}$. en concurrencia con las circunstancias de hecho que, según la ley, hacen procedente la prestación de tales alimentos; v) que al morir alguien le sobrevivieran personas que tenían título legal y reunían las mencionadas circunstancias para haberle demandado alimentos forzosos en vida, que, sin embargo, nunca demandaron ni recibieron a título voluntario, no obstante lo cual el testador ordenó pagárselos como forzosos en su testamento, vale decir, se los legó; y vi) que al morir alguien dejara individuos beneficiarios de título legal y de las mencionadas circunstancias para haberle demandado alimentos forzosos en vida, que nunca demandaron ni recibieron a título voluntario, sin que el testador se los haya legado en su testamento.

Acerca del caso i), vale decir, de las mensualidades de alimentos constituidos en vida del alimentante, algunas de cuyas mensualidades estaban en mora de ser pagadas al morir, en el siglo XIX se sostuvo que tales mensualidades son el único y exclusivo

\footnotetext{
1 Recuérdese que, según el artículo 331 inciso $1^{\circ}$ CC., los alimentos deben ser pagados por mesadas anticipadas. Por cierto, esto no vale cuando la obligación de darlos ha sido satisfecha de un modo incompatible con la idea de "mesada", como si se constituye un usufructo, uso o habitación, según lo permite el artículo 11 de la Ley No 14.908: Sobre abandono de familia y pago de pensiones alimenticias.
} 
contenido de la asignación forzosa de alimentos $^{2}$. En la actualidad, sin embargo, hay acuerdo en que la obligación a tales mensualidades es una deuda hereditaria que debe pagarse a título de baja general de la herencia, según lo prescrito por el artículo 959 No 2 CC., así que la asignación forzosa se refiere a otros alimentos ${ }^{3}$.

La jurisprudencia de la segunda mitad del siglo XIX decidió que los únicos alimentos que dan contenido a la asignación forzosa de tales son los constituidos en el caso ii), vale decir, en vida del alimentante por sentencia judicial o por instrumento auténtico (seguramente con referencia a una transacción) ${ }^{4}$. La del siglo XX añadió los alimentos del caso iii), esto es, aquellos demandados en vida del supuesto alimentante, que murió antes de emitirse la sentencia o transar ${ }^{5}$. La doctrina, con las adiciones que se dirán, se ha uniformado en estos dos pareceres hasta el presente ${ }^{6}$.

En lo que atañe a los alimentos del caso iv), es decir, de aquellos voluntariamente pagados por el alimentante durante su vida, Claro Solar ${ }^{7}$, seguido por Somarriva ${ }^{8}$ y obiter por Domínguez \& Domínguez ${ }^{9}$, ha sostenido la opinión de también quedar incluidos en la asignación forzosa. Esta opinión tuvo el apoyo de alguna jurisprudencia $^{10}$, pero no sin contradicción de otros autores ahora ${ }^{11}$.

En torno al caso v), de alimentos forzosos no exigidos en vida pero sí dejados en testamento, no hemos encontrado opiniones directas y explícitas, pronunciadas después de una problematización del punto, aunque la doctrina da por supuesto que, con un

\footnotetext{
${ }^{2}$ La información procede de AGUIRRE (1891) p. 76, quien, empero, no cita las fuentes.

3 Véase la nota 6.

${ }^{4}$ Véanse las sentencias de 19 de mayo de 1884, confirmada por la Corte de Santiago, en La Gaceta de los Tribunales 2.130 (Santiago, 28 de marzo de 1885), sentencia No 355, p. 192; y de 3 de marzo de 1885, confirmada por la Corte de Concepción, ibíd. 2.169 (Santiago, 26 de diciembre de 1885), sentencia No 3.753, pp. 2225-2226; Corte Suprema, sentencia de 16 de abril de 1906, Revista de Derecho y Jurisprudencia 3 (octubre de 1906) 1, sec. 1a, pp. 294-301 (con nota crítica de L. Claro Solar); Corte Suprema, sentencia de 23 de mayo de 1950, ibíd. 47 (1950) 3-4, sec. 1a , p. 213 (considerandos 4oo, 5o $7^{\circ}$ y 8o). Véanse, asimismo, las sentencias citadas en la nota que sigue.

5 Véanse las sentencias de la Corte de Temuco, de 30 de julio de 1937, Revista de Derecho y Jurisprudencia 37 (1940) 3-4, sec. 2a, p. 22 (considerando 9o); Corte Suprema, sentencia de 10 de agosto de 1954, ibíd. 51 (1954) 7-8, sec. $1^{\text {a }}$, pp. 406-407 (considerando 8º).

${ }^{6}$ Coincidentes en que los alimentos que constituyen la asignación forzosa son, al menos, los establecidos en vida del causante, por sentencia judicial o transacción: CLARO (1942) XV, 1, No 182, pp. 166-167 (sin referirse, no obstante, a los demandados en vida y con el añadido de los voluntariamente pagados); SOMARRIVA (2005), II, No 439, pp. 363-365 (sin referencia, sin embargo, a los transados y con el mismo añadido de Claro Solar); Domínguez y Domínguez (1998) II, párrs. 891-891,1, pp. 903-910 (con el mismo añadido de Claro Solar); Rodríguez (2002) I, p. 290; Elorriaga (2005) No 454, pp. 382-384. No se pronuncia MEZA (2007) No 407, p. 101.

7 Claro (1942) XV, 1, núm. 182, pp. 166-167. Precedentemente había adelantado su tesis en una nota crítica a una sentencia de la Corte Suprema, de 16 de abril de 1906, en Revista de Derecho y Jurisprudencia 3 (octubre de 1905) 1, sec. $1^{\text {a }}$, pp. 294-298.

8 SOMARriva (2005) II, No 439, pp. 363-364.

9 Domínguez y Domínguez (1998) II, No 891, p. 904: "los alimentos respecto de los cuales hay declaración judicial o reconocimiento voluntario del alimentante, han de seguirse pagando como asignación forzosa por la masa hereditaria”.

${ }^{10}$ Citada por Somarriva: véase la nota 8.

11 Rodríguez (2002) I, pp. 289-290; Elorriaga (2005) No 454, p. 383.
} 
legado de alimentos a favor de alguien que tiene título legal para ellos, el testador cumple con el carácter forzoso de la asignación de que tratamos.

Acerca de los alimentos del punto vi), esto es, de aquellos nunca demandados en vida al supuesto alimentario, que tampoco jamás los pagó entonces, ni los legó en su testamento, Aguirre Vargas sostuvo, a fines del siglo XIX, su pertenencia a la asignación forzosa ${ }^{12}$. Pero esta opinión ha permanecido aislada y hoy nadie la sustenta ${ }^{13}$. Ello significa que quienes tuvieron título y circunstancias para haber demandado alimentos a alguien durante su vida y nunca se los demandaron, ya no pueden hacer esto contra los herederos. De poder hacerlo, la obligación de pagarlos nunca hubiera quedado constituida primero en cabeza de quien estaba pasivamente sujeto a cierto título legal de tener que dar alimentos, para después trasmitirse a sus herederos, sino que se constituiría directamente en cabeza de estos, pese a que nunca estuvieron pasivamente sujetos a ese título; así que se daría el caso de una obligación del causante que principia, en realidad, en el heredero. El título para pedir alimentos no es, pues, transmisible y caduca con la muerte de su sujeto pasivo.

b) El segundo problema consiste en determinar si los alimentos debidos por ley a ciertas personas se pagan, al morir el alimentante, solo y exclusivamente con los bienes de la masa hereditaria dejada, de modo que, en defecto de tales bienes, quedan ellos impagos; o si, en el mismo caso, los herederos son los obligados a pagarlos con sus propios recursos, merced, en consecuencia, a su responsabilidad ultra vires hereditatis. Según Claro Solar, a tenor del artículo 1168 CC., para el cual los alimentos forzosos "gravan la masa hereditaria", la primera afirmación es la correcta: "Los herederos a título de tales y como representantes de la persona del difunto no están obligados a suministrar con su propio patrimonio los alimentos que pudo estar obligado a prestar el difunto" ${ }^{14}$; si bien después se contradice ${ }^{15}$. La doctrina posterior es ambigua al respecto ${ }^{16}$.

\footnotetext{
12 Aguirre (1891) pp. 76-91.

${ }^{13}$ Véase la nota 6.

${ }^{14}$ Claro (1943) III, No 1858, p. 489.

15 Claro (1942) XV, 3, No 182, pp. 166-167: "Si la pensión alimenticia fijada por el juez en su sentencia que falló el juicio promovido por el alimentario contra el que le debía alimentos debe ser pagada por sus herederos, ¿por qué no habría de ser también obligatorio para sus herederos el pago de la pensión alimenticia que el alimentario ha estado recibiendo buenamente del alimentante sin necesidad de demandarla? Aunque, acto seguido, traslada el mismo argumento a términos, no de "los herederos" sino de la "masa hereditaria".

16 Ambiguamente a favor de la tesis de Claro Solar: Domínguez y Domínguez (1998) II, No 892, p. 911: "Si no hubiere sobrante [sc. de la masa después de deducidas las bajas $1^{\text {a }}$ a $3^{\text {a }}$ del artículo 959 CC.) es que el causante no podía pagar alimentos porque le faltarían las facultades económicas para ser obligado a su pago", con lo cual parecen dar a entender que los herederos no deben asumir ese pago con sus recursos; pero ibíd., II, No 1044, 1, p. 1168: "los asignatarios de alimentos forzosos no han menester de ninguna acción especial para cobrar su asignación", de manera que si no se les pagan o respetan "pueden cobrarlos directamente de los herederos aun legitimarios" (¿de sus propios recursos, excepto de la legítima en el caso de los últimos indicados?). ElorRIAGA (2005) No 453, p. 381: "Esto [sc. lo que dice el artículo 1168 CC.] demuestra que la obligación alimenticia es intransmisible, dado que ella no pasa a los herederos del de cujus, sino que la obligación grava la masa hereditaria". Ambiguamente en contra de la tesis de Claro Solar: RODRÍGUEZ (2002) I, p. 288: "Se trata, entonces, de una obligación transmisible que deben soportar los herederos, en cuanto continuadores de la personalidad del causante, y que se sigue devengando mientras subsista el alimentario y las circunstancias que legitimaron la demanda". No se pronuncian SOMARrIVA (2005) II, No 438, pp. 362-363; ni MeZA (2007) pp. 100-102.
} 
2. En este trabajo -es preliminar decirlo-, en lo tocante al primer problema antes expuesto, nos conformamos con el actual consenso, en orden a que la asignación forzosa de alimentos al menos contiene aquellos constituidos en vida del alimentante por causa de una sentencia judicial firme o de una transacción judicialmente aprobada (caso ii), y también los que fueron constituidos después de su muerte, siempre que la demanda hubiera sido presentada cuando vivía (caso iii); y que no contiene, en cambio, a los alimentos que alguien pudo haber demandado, con título y circunstancias, a otro en vida, y no los demandó, así que ya no puede después pedirlos a los herederos (caso vi). También aceptamos que las mensualidades de alimentos de que el alimentante estaba en mora de pagar al morir son sin más deudas hereditarias (caso i), aunque al final discutiremos si deban pagarse como baja del No 2 del artículo 959 CC. ${ }^{17}$. En lo referente a los casos iv) o de pago voluntario de alimentos forzosos en vida, y v) o de legado de alimentos forzosos, prescindiremos de su consideración por ahora y trasladaremos la pertinente discusión también al final de este escrito ${ }^{18}$, ya que su momentánea omisión no estorba el análisis que aquí habremos de conducir.

Por lo que respecta al segundo problema, sobre qué bienes soportan el pago de los alimentos forzosos, él ofrece cierta centralidad en el análisis, por lo cual tiene reservado un natural y oportuno lugar ${ }^{19}$, así que nada es necesario adelantar ahora al respecto.

3. Nuestro punto de partida seguro es, pues, el de una persona que se encontraba obligada en vida a pagar alimentos a otra por efecto de una sentencia firme o de una transacción judicialmente aprobada y que muere en una época posterior. Por el momento, prescindiremos también de los alimentos demandados como forzosos en vida del supuesto alimentante que murió antes de la sentencia o eventual transacción [caso iii) del número 1, a)], con el propósito de no recargar el análisis ${ }^{20}$. Para este, son suficientes los dos casos inicialmente indicados.

Ahora bien, de la sola descripción de la hipótesis a que nos hemos circunscrito fluye la evidencia de haber cierta obligación sustentada por un alimentante que vive. No es necesario insistir demasiado, en efecto, en que los alimentos constituyen precisamente el objeto de una obligación cuya fuente es, al menos para el Código, la ley. Ellos son el ejemplo al que recurre el artículo 578 CC., para ilustrar el concepto de derecho personal o crédito que se tiene por causa de la sola disposición precisamente de la ley. El título $18^{\circ}$ de su libro I se rubrica: De los alimentos que se deben por ley a ciertas personas, y esta misma expresión es la empleada para describir la primera de las asignaciones forzosas en la enumeración de tales que ofrece el artículo 1167 CC., con posterioridad al cual comparece la rúbrica del $₫ 1$ del título $5^{\circ}$ del libro III: De las asignaciones alimenticias que se deben a ciertas personas. En consonancia, tanto el articulado de este párrafo como

\footnotetext{
17 Véase, más abajo, el número 9, b).

18 Véase, más abajo, el número 10 , a) y b).

19 Véase, más abajo, el número 5.

20 Sobre ellos, véase, más abajo, el número 9, a).
} 
aquel del título $18^{\circ}$ del libro I están constantemente escritos en términos de "deber" y "obligación", como puede verificarse fácilmente con su lectura. Así que no cabe ni siquiera dudar que los alimentos son un derecho personal o crédito para el alimentario y una obligación o deuda para el alimentante.

Lo que sí puede ser severamente puesto en discusión es el carácter legal de esta obligación, atendida la necesidad de una sentencia judicial que no opera declarativa sino constitutivamente, puesto que, según el artículo 331 inciso $1^{\circ} \mathrm{CC}$., los alimentos exigen una demanda y se deben solo desde la primera. Así que mejor fuere hablar de obligación judicial que supone, eso sí, un título legal. Por lo demás, ha de observarse que es precisamente esta construcción la que explica aquella doctrina que expusimos al principiar como pertinente al caso vi), aunque ninguno de sus sostenedores, que yo sepa, haya asumido el presupuesto. En efecto, si habiendo habido título legal y circunstancias como para haber demandado alimentos, nunca se estableció por sentencia (o transacción) la obligación a su pago y murió el teóricamente sujeto pasivo de ella, de guisa que ahora el teóricamente sujeto activo de la misma ya no puede demandar a los herederos para que contra ellos se constituya la obligación alimenticia, eso solo se debe a que esta no es legal sino precisamente judicial ${ }^{21}$. De todos modos no habremos de entrar en esta materia, que ni es la de nuestro trabajo, ni resulta necesaria para su desarrollo. Como adelantamos, para este es suficiente verificar que, una vez emitida la sentencia que condena entre vivos a alguien al pago de alimentos debidos por ley, o aprobada judicialmente una transacción que los establece, ya hay un derecho personal o crédito para el alimentario y una correlativa obligación o deuda para el alimentante.

4. La obligación alimenticia así establecida entre vivos no se extingue con la muerte del alimentante, aunque sí por aquella del alimentario (artículo 332 inciso $1^{\circ}$ CC.).

a) Si se extinguiera por la muerte de aquel, el alimentario ya no podría exigir su pago con posterioridad. Pero, como hemos visto, todos están de acuerdo en que sí puede exigirlo. Es lo que implícitamente reconoce el artículo 959 No 4 CC., que ordena deducir unas "asignaciones alimenticias forzosas" del acervo o masa de bienes que el difunto ha dejado, con el objetivo de después llevar a efecto sus disposiciones testamen-

\footnotetext{
21 Esta tesis aparece sostenida hace muchos años, Alfonso (1882) I, pp. 612-613. Tal obra, de hecho anónima, pero atribuida a P. Alfonso, según el bibliógrafo Aníbal Echeverría Reyes (1891), registro No 128, p. 63: "Contiene comentarios extensos, tomados principalmente de las lecciones orales dadas en la Universidad [sc. de Chile] por los distinguidos profesores Don José Clemente Fabres y Don Enrique Cood". Hay al menos tres fallos que también sustentan la misma tesis: Corte de Temuco, sentencias de 14 de agosto de 1936, en Revista de Derecho y Jurisprudencia 39 (1942) 5-6, sec. 2a p. 36 (considerando 4o): "Las personas que por ley tienen derecho a alimentos, lo tienen, en general, de un modo abstracto y remoto; para que este derecho exista correlativamente a una obligación civil es preciso que sea declarada o determinada por el tribunal"; Corte Suprema, sentencia de 23 de mayo de 1950, ibíd. 47 (1959) 3-4, p. 213: en el considerando $4^{\circ}$, distingue el derecho a pedir alimentos y la obligación alimenticia; y en el considerando 7o, expresa: "nacida [sc. la obligación alimenticia] como consecuencia del hecho de haberse acogido la acción que concede la ley para pedir alimentos [...]”. En contra VODANOVIC (2004) pp. 25-26, de manera no convincente y con apoyo en alguna jurisprudencia que cita ahí mismo.
} 
tarias o aquellas de la ley. Es, pues, como las denomina la doctrina, una de las bajas generales de la herencia. Así que el alimentario puede exigir el pago de los alimentos forzosos constituidos en vida del alimentante aún después de su muerte; y aquellos deben ser pagados precisamente como baja general de la herencia, o, según dice la ley, del acervo o masa de bienes dejado por el difunto, o acervo ilíquido, como lo llama la doctrina, del cual hay que deducir los bienes necesarios para pagar tales alimentos antes de aplicar las disposiciones del testamento o de la ley, si bien después de las deducciones ordenadas en los números $1^{\circ}$ a $3^{\circ}$ del mismo artículo 959 CC. ${ }^{22}$ En complemento de esta disposición, el artículo 1168 CC. prescribe que los alimentos a que nos estamos refiriendo "gravan la masa hereditaria", punto este al cual nos referiremos después ${ }^{23}$.

Del anterior análisis se colige que la obligación de pagar alimentos forzosos constituidos en vida del alimentante por sentencia o transacción es transmisible; forma de decir equivalente a esta otra: la obligación a tales alimentos no se extingue por la muerte del alimentante.

b) En el uso del verbo "transmitir" y de su negación, y de los sustantivos "transmisión” y "transmisibilidad" y de sus privativos, a propósito de la obligación alimenticia, la doctrina y la jurisprudencia han solido incurrir en confusiones, pues, con tales palabras, la referencia es, ora al problema de qué alimentos son los contenidos en la asignación forzosa de tales, ora al problema de qué bienes son los que soportan el pago de esa asignación.

Se dice, en efecto, que la obligación alimenticia es intransmisible, en función de afirmar la idea de que los alimentos, para demandar los cuales alguien tuvo título legal, sin haberlos, empero, demandado en vida del supuesto obligado a darlos [caso vi) del número 1, a)], ya no pueden ser pedidos por aquel después de la muerte de este a sus herederos. Como es, pues, la muerte la que le impide demandarlos, he ahí entonces que la obligación de dar alimentos sería intransmisible. Una vez dicho esto, no se tiene el cuidado de aclarar que, en cambio, la obligación de dar alimentos constituida en vida del alimentante por sentencia o transacción sí que es transmisible, puesto que la muerte del alimentante no la extingue.

También se dice que la obligación alimenticia es intransmisible en cuanto a que, si faltan bienes en la herencia para su pago, los herederos no están sujetos a cumplirlos con sus propios bienes ${ }^{24}$; pero sin adoptar la precaución de advertir que esta intransmisibilidad es distinta a la anterior.

c) Para poner orden en la materia digamos, pues, lo siguiente: la obligación de dar los alimentos constituidos en vida del alimentante por sentencia o transacción es cierta-

\footnotetext{
22 Por ello es muy extraño lo que expresa VODANOVIC (2004) p. 160: “[...] en Chile la obligación alimenticia no es transmisible a los herederos, pero no se extingue [i!], sino que pasa a ser una baja general de la herencia; es uno de los créditos que se deducen del acervo líquido [sc. por ilíquido] del causante [...]". Pero véase lo que este mismo autor dice según la cita de la nota 25.

${ }^{23}$ Véase, más abajo, el número 5.

${ }^{24}$ Claro (1943) III, núm. 1858, p. 489: "La obligación de prestar alimentos no se trasmite, por consiguiente, a los herederos; es únicamente un gravamen de la masa hereditaria"; y sigue el texto transcrito a propósito de la nota 14 .
} 
mente transmisible, porque tal obligación no se extingue con la muerte del deudor. Con respecto a los alimentos no constituidos en vida del alimentante (ni demandados entonces), el estado al que llegan una vez muerto este se puede describir de dos maneras. La primera es decir que son, en efecto, intransmisibles. La segunda -en armonía con lo antes expresado, en orden a que sin previa constitución en vida del alimentante, no hay propiamente obligación de dar alimentos-, es que no cabe ni siquiera plantear cuestión de transmisibilidad e intransmisibilidad de algo que nunca existió; y que, a lo más, se podría hablar de caducidad del título legal por la muerte del sujeto a él y, por ende, de su intransmisibilidad; y esta es la manera de hablar que preferimos.

d) Pero se agita otra cuestión de transmisibilidad o intransmisibilidad relativa, esta vez, al tema de qué bienes soportan en definitiva el pago de la asignación de alimentos forzosos. Porque, en efecto, si ellos se pagan solo desde el caudal hereditario, a falta del cual no se pagan, es que -se dice- la deuda no es transmisible al heredero; y que sí lo es cuando, a falta de bienes hereditarios, el heredero debe responder con sus bienes propios. Pero el asunto está mal planteado, porque si se acepta la idea de que el heredero no queda sujeto a responder más allá de las fuerzas de la herencia por los alimentos, no por eso la deuda alimenticia deja de ser transmisible, como bien se ve a través de la hipótesis de un heredero que acepta la sucesión con beneficio de inventario, con el cual limita su responsabilidad por las deudas hereditarias hasta el valor de la herencia, sin que por ello tales deudas se hagan intransmisibles. Así que no debe confundirse el problema de la transmisibilidad o intransmisibilidad de la obligación alimenticia con aquel de los límites de la responsabilidad por ella.

Insistamos, pues, en que la obligación de dar alimentos constituida en vida del alimentante por sentencia o transacción es transmisible. Otra cosa es dentro de qué límites se responda por ella.

5. Si la anterior proposición es verdadera, entonces también lo es esta ulterior: que la dicha obligación es una deuda hereditaria ${ }^{25}$. Definida esta como aquella a que

\footnotetext{
25 Claro (1942) XV, 3, No 1371, p. 269, negó expresamente que los alimentos forzosos sean deudas hereditarias: "Esto mismo [sc. que si las bajas generales del No 1 al 3 consumen todo el acervo ilíquido] manifiesta que los alimentos que se deben por ley no tienen el carácter de una deuda hereditaria, que si lo tuvieran deberían concurrir a su pago con las deudas comunes del difunto; y prorratearse con ellas si los bienes dejados por el difunto no alcanzaren a pagarlas íntegramente”. Cfr. Claro (1942) XV, 1, núm.181, p. 165. Pero ibíd., III, núm. 1858, p. 488, al comentar el artículo 1168 CC.: "Según esto [sc. según dicho artículo] la transmisibilidad de la obligación de alimentos ha desaparecido y ha sido sustituida por un gravamen que afecta a la masa hereditaria [...] es una especie de deuda hereditaria”. Por cierto, no se puede decidir acerca de la naturaleza jurídica de ninguna figura sobre la base de un régimen accidental y externo, como es, en este caso, el lugar que los alimentos forzosos ocupan como baja en el artículo 969 CC.; lugar que, por otro lado, encuentra una adecuada explicación, que ofrecemos más abajo, en el número 6. El único, según nuestro conocimiento, que ha reconocido directamente el verdadero carácter de la asignación de alimentos forzosos es MEZA (2007) No 104, p. 43: "Las asignaciones alimenticias forzosas son, en verdad, deudas hereditarias; el causante estaba obligado en vida, por mandato de la ley, a suministrar alimentos a ciertas personas". Se ha acercado a la misma idea RodríGUEZ (2002) I, pp. 96: "Se trata, por lo mismo, de deudas que gravan el patrimonio hereditario y que deben pagarse con preferencia a cualquier otra asignación. [...]. De aquí que esta deuda se trasmita a la sucesión y siga devengándose contra ella
} 
estaba sujeto el causante en vida y que no se extingue por su muerte, la exactitud de esta nueva proposición aparece como incontestable. La obligación que el alimentante satisfacía en vida no sufre alguna transmutación con su fallecimiento, y sigue, pues, en su ser de obligación. Al respecto, no hay diferencia con cualquier otra contraída durante su vida, el deber de satisfacer la cual continúa después de morir.

a) Pero la idea de deuda hereditaria que antes recordamos suele ir complementada con este apéndice: que ellas son de cargo de los herederos, en el sentido de competer a estos su pago, incluso con sus propios recursos (a salvo el beneficio de inventario). Ahora bien, los alimentos forzosos son una baja general de la herencia (artículo 959 No 4 CC.) y el artículo 1168 CC. prescribe que ellos "gravan la masa hereditaria". Claro Solar dedujo que tales alimentos entonces no gravan los bienes propios del heredero ${ }^{26}$, empleando el lenguaje de la intransmisibilidad ${ }^{27}$.

Antes de discutir el punto más a fondo, debe precisarse lo que sigue: como la sucesión por causa de muerte es un modo de adquirir (artículo 588 inciso $1^{\circ}$ CC.), al morir el causante, los herederos se hacen dueños de todos sus bienes transmisibles (artículos 951 inciso $2^{\circ}$ y 1097 inciso $1^{\circ}$ CC.), supuesta la aceptación de la herencia (artículo 1239 inciso $1^{\circ}$ CC.). Que los alimentos forzosos se paguen como baja general de la herencia (artículo 959 No 4 CC.), no implica que no se paguen -es casi innecesario decirlo- con bienes de la herencia. Se pagan, pues, con bienes que se hicieron de los herederos. Tanto es así, que eso repercute necesariamente en el volumen de valor concreto que cada cual recibirá por su cuota hereditaria, al aplicarse esta a un acervo del que se han separado previamente los alimentos. La contraprueba manifiesta es que, al cesar la obligación de pagar alimentos, por ejemplo, por haber mejorado la condición económica del alimentario o por su fallecimiento, lo que haya subsistido de los bienes que se destinaron a su satisfacción, es restituido a los herederos ${ }^{28}$ y repartido entre ellos confor-

-contra los herederos- en beneficio del titular./ Hay, por lo tanto, poderosas razones para afirmar que se trata de una deuda [...]"; (p. 97): [L]a ley ha dado a esta asignación [...] el alcance de una obligación vigente que pesará, por cierto, sobre los herederos como continuadores de la personalidad del causante". En algunas sentencias así se ha dicho; por ejemplo una de la Corte de Concepción, de 18 de octubre de 1938, en Gaceta de los Tribunales (1938, $2^{\circ}$ semestre), sent. No 98, p. 463 (considerando No 6o): "En cierto sentido, esta obligación que pesa sobre el patrimonio dejado por el difunto constituye una especie de deuda hereditaria, con todas las características que le son propias a esta especie de carga". VODANOVIC (2004) p. 161 hace suyas estas palabras (aunque véase la nota 22). Pero estos autores no han desarrollado la idea ni concluido con base en ella.

${ }^{26}$ Véase su texto citado a propósito de las notas 14 y 24. Pero estos autores no han desarrollado la idea ni concluido con base en ella.

27 Véase la nota 24.

${ }^{28}$ Véase el artículo 333 CC.: si un capital fue consignado en una caja de ahorros o en otro establecimiento análogo, para pagar los alimentos con los intereses que produzca, al terminar la obligación se restituye el capital -dice la norma- al alimentante o a sus herederos. Ahora bien, la disposición cubre indiscutiblemente los siguientes casos: i) que el alimentante haya sido condenado en vida y entonces haya sido consignado el capital: si la obligación alimenticia termina durante su vida, a él se restituye el capital; ii) en el mismo caso, con la variante de que el alimentante haya muerto al cesar la obligación (lo que supone que no se innovó en el régimen de pago que venía desde que el alimentante vivía): el capital es restituido a sus herederos. Hay una tercera hipótesis: que al morir el alimentante, solo entonces se haya hecho la consignación de capital para pagar los alimentos con sus intereses (lo que implica innovación en el régimen que 
me con las reglas generales; con toda razón, porque son suyos. De esta manera, el artículo 959 No 4 CC. también significa que los alimentos forzosos constituidos en vida del causante los soportan, en principio, los herederos. Lo cual es concorde con que tales alimentos son transmisibles. Por consiguiente, aquella disposición nada dice en contra de la transmisibilidad de la obligación alimenticia; en el mismo sentido, por lo demás, en que nada en contra de la transmisibilidad de las deudas hereditarias dice el No 2 del mismo artículo, cuando también las considera bajas generales. De hecho, este artículo fue escrito tan solo para dar cierta preferencia de pago a los rubros que contiene.

De esta forma, que la obligación a los alimentos se pague como baja general, eso no excluye que sea transmisible ni que su pago no grave las asignaciones de los herederos.

b) Despejado así el significado de que los alimentos sean baja general de la herencia, resalta mejor el verdadero problema, que es el de saber si los herederos están sujetos a cumplir la obligación alimenticia de su causante con sus bienes propios, en el caso de insuficiencia o ausencia de bienes hereditarios.

A este respecto se presenta la dicción del artículo 1168 CC., en orden a que los alimentos "gravan la masa hereditaria", la cual puede significar dos cosas:

i) El primer significado es en oposición a que ellos graven las asignaciones de cada heredero a prorrata de las mismas; lo cual redundaría en que estos, con independencia, pues, de tales cuotas, deban soportar por partes iguales su pago, a menos que el testador lo imponga a uno o a varios herederos (o legatarios), como lo permite el artículo 1168 CC. ${ }^{29}$. Todo ello a diferencia de las deudas hereditarias, que si bien son asimismo bajas y se deducen previamente, en final de cuentas no gravan la masa, sino a cada heredero a prorrata de sus cuotas (artículo 1354 CC.) ${ }^{30}$. Tal es, pues, uno de los significados de "gravar a la masa hereditaria", cuyo opuesto no es "ser intransmisible", sino "gravar las cuotas hereditarias (a prorrata)". De este modo, el sentido de la expresión usada en el artículo 1168 CC. sería el mismo con que es empleada una expresión semejante en el No 4 del artículo 959: "Los impuestos fiscales que gravaren toda la masa hereditaria", en donde el opuesto de "toda la masa hereditaria" es "cada asignación en particular". En tales circunstancias, la norma nada diría acerca de quién soporta finalmente el pago de los alimentos: si solo la herencia, o también los herederos con su propio patrimonio (normalmente antes la insuficiencia de los bienes del difunto).

usaba el alimentante condenado en vida, quien tal vez pagaba directamente las mesadas); en determinado momento, cesa la obligación alimenticia a cargo de los herederos: es evidente que el capital debe serles restituido. Pero, en realidad, este caso se haya previsto en la letra del artículo 333 CC., porque ahora son los herederos los alimentantes.

29 El artículo 1168 dice: “a uno o más partícipes en la sucesión”; y esta dicción cubre, por cierto, a los herederos, pero también a los legatarios (que, para la ley, son sucesores, aunque a título singular: artículo 951 CC.); y en realidad no se ven obstáculos para pensar en que el testador no pueda imponer el pago de los alimentos forzosos a un legatario.

30 Como las deudas hereditarias se deducen previamente por ser bajas, en cuanto a ese pago inmediato, los herederos contribuyen por partes iguales, pero no necesariamente lo soportan así, y después, tal vez en la partición, en el momento de determinar los alcances, se deben distribuir los montos de las deudas ya pagadas (o, eventualmente, por pagar) de acuerdo con las cuotas de cada heredero. Por ello es indebido 
ii) El segundo significado posible de nuestra dicción es el que le atribuía Claro Solar ${ }^{31}$, vale decir, precisamente que el pago de los alimentos grava los bienes hereditarios, y solo a ellos, mas nunca los bienes propios de los herederos; de lo cual nosotros deducimos, en complemento, que estos responden de tales alimentos no solo "dentro de las fuerzas de la herencia" (intra vires hereditatis), pero también "con las fuerzas de la herencia" (cum viribus hereditatis). Así que, si no hay bienes sucesorios para pagar los alimentos, el alimentario no puede reclamar su pago a los herederos, para que los satisfagan con los suyos, ni siquiera concediéndoles la limitación del pago al valor permitido por las fuerzas de la herencia.

La interpretación de Claro Solar resulta acorde a la naturaleza de asignación hereditaria que el Código reconoce a los alimentos forzosos, pues va de suyo que tales asignaciones sean cumplidas con bienes de la herencia, como todas las asignaciones hereditarias, y en la medida de sus fuerzas. Pero también es cierto que si los alimentos forzosos son, en realidad, deudas hereditarias, ya no hay concordancia porque estas son de cargo final de los herederos, incluso más allá de las fuerzas de la herencia (o de las fuerzas de la asignación de cada cual, aunque a prorrata de esta).

Claro Solar ${ }^{32}$ aducía en apoyo de su interpretación la historia legislativa del artículo 1168 CC., cuyo texto fue introducido, con tal número, en el "Proyecto de $1855^{\prime}$, presentado a la aprobación del Congreso Nacional ${ }^{33}$; pero en sustitución de un artículo 1325 del "Proyecto Inédito", que declaraba: "La obligación de prestar alimentos no se transmite a los herederos sino a favor de las personas designadas" en solo determinados números del artículo 360, que, en el libro sobre personas del mismo proyecto, señala a los titulares, ya entre vivos, de alimentos forzosos ${ }^{34}$. La eliminación de esta norma fulminada en el "Proyecto de 1855" y su reemplazo por el artículo 1168 en él y, por ende, en el Código sería, pues, índice de un cambio de concepción legal. Que para el "Proyecto Inédito" la obligación alimenticia se transmitiera a los herederos significaría que estos quedarían obligados a subvenirlos incluso en defecto de bienes sucesorios; en tanto que, para el "Proyecto de 1855" y el Código, ello no debía acaecer, porque los alimentos se pagan con cargo exclusivo a la masa de bienes, y en su medida, pues tal sería el sentido de la expresión "gravan la masa hereditaria". Pero esta conclusión no es literalmente segura, porque la idea de transmisión de la obligación alimenticia recurrida por el sustituido artículo 1325 del "Proyecto Inédito" decía algo tan verdadero, que ni siquiera en el Código deja de serlo, a saber: que la obligación de prestar alimentos se

establecer una correlación entre el hecho de ser algo baja general y el de gravar eso mismo la masa. Así SOMARRIVA (2005) núm. 437, p. 363: "La regla general es entonces que los alimentos forzosos graven la masa hereditaria; dicho de otra manera, constituyen una baja general de la herencia". Como se ve, no es así: una cosa es ser baja y otra distinta si las asignaciones quedan gravadas o no por esa baja, como se ve en el caso antes expuesto de las deudas hereditarias.

${ }^{31}$ Véase a propósito de la nota 14.

32 Claro (1942) XV, 3, No 181, pp. 165-166.

33 Proyecto de Código Civil (1855) p. 307.

${ }^{34}$ En Bello (1890) XIII, p. 300. 
trasmite a los herederos, porque no se extingue con la muerte del alimentante, sin prejuzgar necesariamente acerca de los límites de la responsabilidad de esos herederos, que es otra cuestión. La interpretación de Claro Solar quedaría respaldada sin más por el texto, si este dijera "gravan solo la masa hereditaria"; pero al decir nada más que "gravan la masa hereditaria", da lugar a la primera interpretación.

Si embargo, Claro Solar tenía razón. El artículo 1168 CC. de todos modos quiso decir lo que sin más discusión hubiera dicho si al verbo "gravar" se le hubiese añadido un adverbio como "solo" o "exclusivamente"; esto es, quiso gravar a la herencia y únicamente a ella, con exclusión del patrimonio propio de los herederos. Dos argumentos tenemos para colegirlo.

Uno deriva de la segunda parte del artículo 1168 CC: "menos cuando el testador haya impuesto esa obligación a uno o más partícipes de la sucesión”. Se trata de saber si la citada norma, al expresar que el testador puede imponer la obligación de los alimentos a algunos partícipes, lo que quiere decir es que entonces eventualmente se grava el patrimonio de tales partícipes. La respuesta es positiva. Se observará que ahí se habla de la persona de los partícipes, no de sus asignaciones. Esto es importante de ser recalcado, porque sigue en pie que los alimentos gravan las asignaciones de los partícipes, en cuanto el pago de aquellos necesariamente disminuye la cuantía de estas, como antes quedó aclarado ${ }^{35}$. Pero tan importante como aquello es comprender que la manera de hablar de la norma implica que es el partícipe (el heredero) mismo el gravado, es decir, su patrimonio personal, no solo su asignación. De esta guisa, lo que expresa dicha norma es que el testador puede imponer el pago de los alimentos de tal modo que finalmente se consuman las asignaciones de los herederos gravados ${ }^{36}$ y se alcance incluso a sus patrimonios personales ${ }^{37}$, sin perjuicio, por cierto, del beneficio de inventario ${ }^{38}$. Si es así, entonces la primera parte del artículo 1168 CC. significa que, en el silencio del testador, los alimentos forzosos gravan únicamente a la masa, para excluir que graven el patrimonio de los herederos, única manera de que la

\footnotetext{
35 Conviene aclarar, complementariamente, que el caso bajo examen no impide que los alimentos forzosos a cargo de un partícipe en al sucesión siga bajo al consideración de baja general; con la peculiaridad de que, en algún momento posterior (por ejemplo, en la partición) el pago de tales alimentos se imputen solo al que estaba expresamente gravado.

36 Siempre que por esta vía no se menoscaben las legítimas, insusceptibles de recibir gravámenes (artículo 1192 CC.).

${ }^{37}$ Los autores no problematizan el punto relativo la extensión de la responsabilidad del heredero expresamente gravado con el pago de alimentos forzosos por el testador, vale decir, si responden solo hasta por su emolumento o también con sus bienes propios; y, en general, o nada dicen al respecto o son ambiguos. Véase Claro Solar (1942), XV, 3, No 1368, p. 269, quien nada dice acerca del heredero (y solo da el ejemplo de un legatario gravado, que no ofrece problemas: véase la nota 38); SOMARRIVA (2005) II, No 437, p. 363 (absoluto silencio); MEZA (2007) No 406, p. 101 (absoluto silencio); RodrígueZ (2002) p. 294 (absoluto silencio); Elorriaga (2005) No 453, p. 382, ambiguo: "Habrá de entenderse que el testador tendría que asignar una parte de los bienes a ese heredero para satisfacer estas necesidades alimenticias [...]". DomíngueZ y Domínguez (1998) No 893, p. 911, dicen obiter, tratarse de una carga: "En ese caso, el gravado es el que debe asumir el pago de la obligación alimenticia, como una carga de su asignación".

${ }^{38}$ Los legatarios (véase la nota 29), en cambio, no ven alcanzados sus patrimonios personales y responden de los alimentos solo hasta el monto del emolumento de su legado, pues se aplica el artículo 1367 a los que hayan sido cargado con el pago de ciertos alimentos.
} 
segunda parte sea una excepción (“menos”) a la primera. Si, en cambio, se sostiene que la segunda parte nada más implica que queda gravada la asignación, entonces la primera parte, al denotar que los alimentos gravan la masa hereditaria, lo único que significaría es que ellos no gravan las asignaciones en particular a prorrata, única manera de que la segunda sea una excepción; en otras palabras, significaría que esa primera parte tiene el primer significado discutido más arriba.

El otro argumento lo desprendemos de la segunda parte del artículo 1170 CC.: "[...] podrán rebajarse los alimentos futuros que parezcan desproporcionados a las fuerzas del patrimonio efectivo". Bajo el supuesto de que la expresión "patrimonio efectivo" mienta el acervo sucesorio ilíquido deducidas las bajas generales de los números 1 y 2 del artículo 959 CC., resulta entonces claro que el monto de la obligación de prestar alimentos por causa de muerte es mirada con relación a dicho acervo, tanto, que si es insuficiente, puede aquel ser rebajado y que -añadimos- si es inexistente, ello hace que, con mayor razón, se extinga la obligación. Ahora bien, si el heredero respondiera con su propio patrimonio de la obligación alimenticia, la norma en examen no se justificaría, porque la insuficiencia del patrimonio efectivo, o su ausencia, tendrían que ser suplidas por el heredero con lo suyo. En otras palabras, si tal fuere el caso, "las fuerzas del patrimonio efectivo" tendrían que ser indiferentes para el monto y aun existencia de la obligación de prestar alimentos.

Así que, en síntesis, que los alimentos forzosos graven la masa hereditaria, según lo dice el artículo 1168 CC., quiere decir que es exclusivamente ella la que los paga y no (subsidiariamente) los bienes de los herederos, o, por mejor decir, no ella "y" los bienes del heredero. Ahora bien, esto es un obstáculo a que los alimentos forzosos sean una deuda hereditaria, porque las deudas de este género son soportadas por los herederos ultra vires hereditatis, esto es, incluso con sus propios bienes. Que no sea así, conviene más, como quedó dicho, al carácter de asignación hereditaria que el Código reconoce a los alimentos.

c) Nos encontramos, pues, en presencia de una figura híbrida. Por un lado, no cabe duda que la obligación de prestar alimentos contraída en vida del alimentante es una deuda hereditaria, que, por consiguiente, se transmite a sus herederos, porque no se extingue por la muerte de su deudor, de guisa que los últimos deben cumplirla. Por otro, esta deuda hereditaria i) no sigue la regla general de las de su género, de deber ser soportadas por los herederos ultra vires hereditatis, o sea, con recursos propios si son insuficientes o inexistentes los dejados por el difunto, pues queda limitada precisamente a las fuerzas de la herencia (artículos 1170 y 1168 CC.). Claro que esta característica de los alimentos forzosos no es incompatible con la de ser deudas hereditarias, si recordamos el efecto que produce el beneficio de inventario con respecto a la generalidad de tales, de limitar la responsabilidad de los herederos por las deudas hereditarias hasta concurrencia del valor total de los bienes que han heredado (artículo 1247 CC.). Así que podemos, pues, construir para el caso de la deuda alimenticia una suerte de beneficio legal de inventario de que gozan los herederos frente a su pago.

Con una nueva peculiaridad ahora con respecto al beneficio de inventario normal: que mientras este, al limitar la responsabilidad de cada heredero por las deudas heredita- 
rias ordinarias al valor de su cuota en la herencia, no impide que la prorrata limitada de las deudas por la que debe responder le sea reclamada sobre sus bienes propios ${ }^{39}$, la responsabilidad que impone al heredero la deuda hereditaria de alimentos forzosos constituidos en vida del alimentante, junto a la limitación impuesta a la responsabilidad por las fuerzas de la herencia, añade ii) la limitación de tener que hacerse efectiva ella solo con los bienes de la herencia (cum viribus hereditatis), sin poder extenderse, pues, a los propios del heredero, aunque solo hasta concurrencia del valor de la herencia. Esta peculiaridad deriva de lo dispuesto por el artículo 1168 CC., como pensaba Claro Solar, y del propio artículo 1170 CC. Del primero, porque los alimentos gravan la masa hereditaria, es decir, los bienes del difunto, no los bienes del heredero. Del segundo, porque cuando se han rebajado los alimentos forzosos a los límites permitidos por las "fuerzas del patrimonio efectivo", esto es, del acervo ilíquido, una vez deducidas las bajas de los números 1 y 2 del artículo 959 CC., no por ello hay que omitir el pago de tales alimentos rebajados como baja del No 4 del artículo antes citado; así que procede igualmente pagarlos con los bienes del acervo ilíquido que haya, una vez saldadas las bajas de los números 1 y 2 del artículo 959 CC.; y no se ve por qué habría de empezar a pagárselos con bienes extrasucesorios, o sea, con los del heredero. Si se diere el caso que nada quede en el acervo ilíquido, después de deducidas las bajas preferentes de los números 1 y 2 , es que la obligación de pagar los alimentos se reduce a cero, porque a cero montan las fuerzas del patrimonio efectivo, vale decir, se extingue; así que tampoco cabe pasar a los bienes propios del heredero ${ }^{40}$.

Cabe indagar si es también una peculiaridad de la deuda hereditaria de alimentos forzosos, con respecto a las deudas hereditarias normales, que iii) ella resulte soportada por los herederos (bien entendido que en cuanto dueños de la herencia), no a prorrata de sus cuotas - como en la generalidad de las deudas hereditarias-, sino por partes iguales. Como vimos, el hecho de ser bajas generales los alimentos no es argumento para decidirse por la paridad, porque las deudas hereditarias también son bajas y sin discusión no hay paridad para su pago; de modo que nada obsta a que, si bien el primer impacto del pago de los alimentos como baja implique una paridad provisional, esta sea eliminada y conducida a una prorrata, por ejemplo, en la partición. Por otro lado, la paridad puede ser uno de los significados del artículo 1168 CC. Ahora bien, nosotros hemos optado por atribuirle el segundo significado, el cual ciertamente no implica de suyo la paridad. Y no hay otros argumentos para apoyarla. Así que nosotros debemos optar por pensar que no la hay y que en este punto los alimentos forzosos imponen su naturaleza de deuda hereditaria, a saber, que, sin perjuicio de su pago inicial como baja

\footnotetext{
39 Domínguez y Domínguez (1998) I, No 25, pp. 62-63.

40 Pudiere acaecer que no se haya provisto en su momento lo necesario para el pago de ciertos alimentos forzosos como baja del No 4 del artículo 959 CC.; por ejemplo, que no se haya constituido un capital, con cuyos intereses hayan de pagarse las mensualidades alimenticias; y esto, por cualquier razón accidental. Tiempo después de liquidada toda la herencia, se presenta el alimentario reclamando su derecho; pero no hay ya bienes sucesorios para su pago. Estimamos aplicable la segunda parte del artículo 1170 CC.: el derecho de alimentos hay que ajustarlo a las fuerzas del patrimonio efectivo y, en el caso propuesto, eso significa que debe ser rebajado a cero; vale decir, se extingue la deuda.
} 
de la herencia, en final de cuentas deba ser distribuido su monto a prorrata de las cuotas de los herederos ${ }^{41}$, cuando proceda ${ }^{42}$.

Ahora bien, ninguna de las dos primeras especialidades y peculiaridades atenta contra el carácter de deuda hereditaria que tenemos reconocido a los alimentos en examen, porque ellas guardan relación con aspectos accidentales de su régimen y no con su sustancia. Pero sí le confieren unos rasgos inusuales con el régimen de las deudas hereditarias, a saber, que se responda por los alimentos hasta el límite determinado por las fuerzas de la herencia, sin necesidad de impetración del beneficio de inventario; y que, además, se responda solo con bienes de la herencia y no con bienes personales. Tales rasgos, anómalos como decimos en una deuda hereditaria, son, en cambio, normales de una asignación hereditaria. Así que resulta ostensible la doble naturaleza con que han sido finalmente configurados los alimentos forzosos en el Código.

6. Pero entonces emerge un problema: si los alimentos forzosos son deudas hereditarias, ¿por qué el artículo 959 CC. separa ambos rubros, cuando menciona en su No 2 a las deudas hereditarias y en su No 4 a los alimentos forzosos? Hubiera bastado el No 2.

La objeción no es difícil de superar.

a) Preliminarmente se observará que todos los rubros del artículo 959 CC. son deudas, aunque de diferente clase: el rubro del No 1, en efecto, en rigor contiene deudas $^{43}$ que en algún momento fueron contraídas por alguien. Si la ley las denomina "costas" (lo que opaca su verdadero carácter) es porque le interesa mirarlas, no inexactamente, en cuanto gastos. Claro es que no se trata de deudas hereditarias, porque no las tenía el causante en vida de modo de haberse trasmitido con su muerte y nacen después de esta; tampoco son deudas testamentarias, pues no encuentran su fuente en el testamento; de hecho provienen del acto o contrato entre vivos que se celebre para la operación sucesoria de que se trate, y que se hacen del o de los herederos todos, bien porque la contrajo el único herederos o todos de consuno, bien porque uno de varios la contrajo

41 Por lo demás, es del todo equitativo que se siga la regla de la prorrata: ¿por qué el heredero de menor cuota ha de contribuir igual que el heredero de mayor cuota a los alimentos forzosos?

42 En la práctica de muchos casos, el prorrateo va ínsito en el modo de pagarse los alimentos. Supóngase que corresponden alimentos de 1.200 mensuales y hay tres herederos, uno por un medio y dos por un cuarto cada uno. La prorrata exige que el heredero de un medio contribuya con 600 y los dos restantes con 300 cada uno. Si para la satisfacción de tales alimentos se constituye un usufructo sobre cierto bien hereditario (cuyo dominio es de los herederos sin discusión a prorrata) de un valor tal, que permita calcular la obtención de frutos civiles (rentas de arrendamiento) de 1.200 al mes, en esta suma va ínsita la prorrata, pues la renta de 1.200 pertenecería en otro caso a los herederos a razón de 600, 200 y 200, de modo que es en estas proporciones que contribuye cada cual. Y se ve que hay prorrata en el hecho de que si la renta fuera de 1.800 (por ejemplo, porque no hay inmuebles que produzcan no más de 1.200), el alimentario tendría que devolver 600 mensualmente en proporción de 300, 150 y 150 a cada heredero y no de 200, 200 y 200. Y si se acuerda que los alimentos se paguen como nueva obligación separadamente contraída entre vivos por los herederos para con el alimentario, es claro que cada cual solo debe obligarse a prorrata. Lo propio acaece si acuerdan las partes la atribución de cierta suma alzada y única como alimentos, cuya reunión por los herederos, pues, debe ser a prorrata.

43 Conforme Rodríguez (2002) I, p. 93: "Se trata de obligaciones asumidas en beneficio de todos los asignatarios $[\ldots] "$. 
por sí en cuanto a su cuota y como agente oficioso (o eventualmente como mandatario) en cuanto al resto de los herederos por las suyas ${ }^{44}$.

El carácter obligacional del rubro contenido en el No 2 fluye de suyo, pues se trata de las deudas hereditarias. El No 3, que mienta los impuestos fiscales que gravaren toda la masa hereditaria, como es sabido, no recibe aplicación, pues los impuestos sucesorios vigentes recaen sobre cada asignación; pero igual nos sirve en función de nuestro actual tema, por ser evidente que los impuestos sucesorios, graven toda la masa, graven cada asignación, en realidad son obligaciones tributarias, o sea, deudas, aunque no hereditarias ni testamentarias, sino legales ${ }^{45}$.

En estas circunstancias, que el rubro del No 4: "Las asignaciones alimenticias forzosas" esté constituido por deudas nada de particular tiene y en ello solo sigue la regla general de las bajas. Y es lógico que sea de esta manera, porque si los alimentos ya eran una obligación del causante en vida, como alimentante, nada nuevo se presentó que haya mudado su naturaleza de tal por el solo hecho de morir él, salvo en el rasgo adjetivo de pasar entonces a ser hereditaria.

b) Ahora bien, el hecho de que el artículo 959 CC. haya separado la deuda hereditaria de alimentos forzosos del rubro general de las deudas hereditarias contenido en su No 2 y creado un lugar específico para ella en el No 4, se explica bien. De hecho, la explicación quedó adelantada, aunque para otros efectos: se trata de deudas hereditarias tan especiales, y aun peculiares, que merecen una consideración aparte. Sus especialidades y peculiaridades quedaron resumidas más arriba ${ }^{46}$. Además, la ley quiso que estas deudas hereditarias en que consisten los alimentos forzosos constituidos en vida del causante gozaran de una preferencia para su pago, posterior a las deudas hereditarias ordinarias. De todas estas circunstancias, pues, derivó la necesidad de separar la deuda hereditaria de los alimentos forzoso de las demás deudas hereditarias.

7. El verdadero problema que plantea la consideración de los alimentos constituidos en vida del alimentante como deudas hereditarias consiste en saber cómo es que o en qué sentido son asignaciones forzosas, y por qué.

a) El carácter forzoso de cierta asignación estriba en constreñir al testador a formularla y en asegurarla al beneficiario aun en contra o defecto de la voluntad del testador, y tal es lo que viene a expresar el artículo 1167 inciso $1^{\circ}$ CC. Pero si los alimentos forzosos constituidos en vida del testador son deudas suyas que subsisten después de su muerte y se trasmiten, por ende, a quienes le hereden, el solo hecho de ser deudas asegura al alimentario su pago, sin ser necesaria una declaración expresa del

\footnotetext{
${ }^{4}$ No está dicho que las “costas” sucesorias se distribuyan finalmente por partes iguales entre los herederos y ello ciertamente no se deduce de que sean una baja general; así que es claro que los herederos deben soportar en fin de cuentas estas "costas" a prorrata de sus cuotas; a lo que debe procederse en la partición.

45 El artículo 959 contenía un No 5, relativo a la "porción conyugal a que hubiere lugar en todos los órdenes de sucesión, menos en el de los descendientes legítimos”, derogado por el artículo 1 No 71 de la Ley No 19.585. Ahora bien, la porción conyugal, al menos aquella pagadera cuando operaban los órdenes sucesorios desde el segundo en adelante, era un crédito del cónyuge sobreviviente.

46 Véase el número 5, c).
} 
testador, sin que obsten una declaración contraria ni su silencio y sin resultar menester que la ley supla lo uno o lo otro. Todo esto es, por lo demás, cuanto acaece con la generalidad de las deudas hereditarias. Fuere, en efecto, superfluo, amén de muy extraño, que la ley declarara que el pago de las deudas hereditarias ordinarias es una asignación forzosa, que el testador está obligado a hacer y que se suple aun en perjuicio de sus disposiciones testamentarias. Así también los alimentos, que han de ser, pues, de todos modos pagados, no por ser asignaciones forzosas sino por ser deudas; y que han ser siempre cobrados por el alimentario, como crédito suyo que es, sin necesidad de pedir que se reforme el testamento.

b) Con esto último queda explicado el silencio que guarda el Código en torno a una eventual legitimación activa de los alimentarios forzosos para la acción de reforma del testamento. Aquel, en efecto, solo confiere tal legitimación a los legitimarios por su legítima, sea rigorosa, sea efectiva, y por su mejora, a los cuales se añadía el cónyuge sobreviviente para pedir su porción conyugal, antes de que la Ley No 19.585 derogara el artículo 1221 CC. que le concedía tal legitimación. Nada dice, pues, acerca de los alimentarios forzosos. Aguirre Vargas y Claro Solar, al tomar noticia de este silencio, opinaron que de todos modos ellos disponen de la acción ${ }^{47}$. Hoy la mayoría opina que no disponen de ella por ser innecesaria o, mejor, por carecer de sentido dársela, atendido el carácter de baja general de la herencia que ofrecen los alimentos, de modo de deber pagarse antes de ser ejecutadas las disposiciones testamentarias ${ }^{48}$. Es la doctrina correcta, con el siguiente matiz: independientemente de que los alimentos sean baja general, los alimentarios forzosos son acreedores hereditarios y, por ende, exigen su crédito merced a una acción personal y ejecutiva ${ }^{49}$ propia, que tenían desde antes de morir el causante contra él y, después de morir, contra sus herederos, en los términos del artículo 1377 CC. ${ }^{50}$, distinta, por cierto, de la acción de reforma de testamento. Ahora bien, ningún acreedor dispone de esta última ni podría disponerla; en consecuencia, tampoco los alimentarios forzosos.

c) Nuestra respuesta, pues, a la pregunta inicial, de saber cómo es que o en qué sentido son asignaciones forzosas los alimentos, es bien radical: los alimentos propiamente no son asignaciones forzosas sino deudas hereditarias. Cuando, sin eliminar la figura de los alimentos forzosos entre vivos, se eliminare su mención en el elenco de asignaciones forzosas del artículo 1167 CC. y todo el $\$ 1$ del título $5^{\circ}$ del libro III del Código, cuyas normas fueren distribuidas en los departamentos apropiados de ese libro

\footnotetext{
47 Así Aguirre (1891) p. 102. Le sigue Claro (1942) XV, 3, No 1638, pp. 274; pero ibíd., p. 544, un tanto olvidado de lo que había dicho precedentemente, tan solo recuerda que los alimentos forzosos se pagan preferentemente como baja general "lo que en el hecho importará una reforma del testamento"; lo cual repite MEZA (2007), núm. 522, p. 127.

48 Así: Domínguez y Domínguez (1998) II, No 1044, 1, p. 1168; RodrígueZ (2002) II, p. 91; ELORRIAGA (2005) pp. 491-492.

49 Véase la nota 50.

${ }^{50}$ Puesto que la obligación de alimentos fue constituida por sentencia judicial firme o transacción aprobada judicialmente, la deuda alimenticia consta en un título ejecutivo oponible a los herederos en los términos de la disposición indicada.
} 
en donde tienen verdadera cabida ${ }^{51}$; en otras palabras si se omitiere declarar asignación forzosa a los alimentos debidos por ley, igual los deberían los herederos, no por ser asignación forzosa, ya que -es nuestro supuesto- no tendrían tal carácter, sino por ser deudas transmisibles del causante. En verdad, haberles atribuido la naturaleza de asignación forzosa nada sustancial les añade y, lo que resulta más importante, no les cambia su verdadera naturaleza de deudas hereditarias.

8. Si la figura de los alimentos forzosos es mirada como aquí hemos hecho, el legado de alimentos forzosos [caso v) del número 1], cuya consideración dejamos pendiente y ahora examinamos, adquiere una fisonomía bien particular. Puede, en efecto, darse el caso de un alimentante, vale decir, de aquella persona que en vida fue condenada al pago de alimentos forzosos por sentencia o que se obligó a los mismos por transacción judicialmente aprobada, que en su testamento disponga un legado de los dichos alimentos. La posibilidad de un tal legado deriva del artículo 1171 inciso $2^{\circ}$ CC. ${ }^{52}$.

Ahora bien, de que los alimentos en referencia adquieren la calidad de deuda hereditaria dejada por el alimentante al morir, se sigue que cuando este dispone por legado su pago, tal disposición viene a ser un caso especial del legado previsto en general por el artículo 1131 CC.: se trata, en efecto, de un legado de lo debido al acreedor (al alimentario).

Así que tal legado debe someterse al régimen previsto en la disposición citada; vale decir:

i) El legado de alimentos forzosos debe ser expresamente formulado a título de tales, de cualquier manera que ello se diga, una de las cuales es la indicada por el artículo 1131 inciso $1^{\circ}$ CC.: que se hace a cuenta del crédito, vale decir, de los alimentos forzosos. Mas puede haber otras. Lo importante es que se manifieste de algún modo el título, o que por las circunstancias "apareciere claramente que la intención del alimentante-testador es pagar la deuda alimenticia con el legado", para parafrasear la dicción de la norma. En caso contrario, el legado es ordinario y, en principio, la previa deuda de alimentos no se extingue con él. Claro que si el legado de que hablamos fuere de una magnitud tal que con él se modificare permanentemente la situación económica del alimentario, de modo que ahora sus medios le alcanzan para subsistir de un modo correspondiente a su posición social, entonces el legado ordinario provoca reflejamente el efecto de extinguir la obligación alimenticia, o de rebajarla

\footnotetext{
${ }^{51}$ En efecto, el actual $\$ 1$ del título $5^{\circ}$ carece de sustancia propia. Sus artículos 1168 y 1170 pertenecen al título 11\%: Del pago de las deudas hereditarias y testamentaria; y el artículo 1171 del mismo título hace parte, bien del $\$ 3$ : De las legitimas y mejoras, en donde, como es sabido, se habla también de las porciones de libre disposición, bien del artículo 1134 CC., en donde se habla de los alimentos voluntarios, que es, bien mirado, el tema de ese artículo 1171 .

52 Se trata ahí, en efecto, de asignaciones alimenticias (legados) que se hacen a alimentarios forzosos.
} 
(artículo 330 CC.). En el evento contrario, como decimos, el legado y la deuda de alimentos son compatibles.

ii) Si consta, pues, que se trata de un legado de alimentos forzosos, el inciso $2^{\circ} \mathrm{del}$ artículo 1131 CC., aplicado al caso, ofrece esta alternativa al arbitrio del acreedoralimentario: exigir el pago de los alimentos en los términos en que fijó el testadoralimentante en su legado o en los términos en que este se hallaba obligado en vida, por la sentencia judicial que lo condenó o por la transacción en que reconoció su deuda alimenticia.

Hasta ahí el artículo 1131 CC. Pero hay otras reglas que tener en cuenta, aplicables a este especial legado de lo debido:

iii) Cuando su monto coincide con el derivado de la sentencia o transacción, el legado es, en realidad, superfluo, pues reitera en todo la deuda; a menos que, por algún elemento accidental que contenga, mejore su condición, por ejemplo, en cuanto al día del pago ${ }^{53}$.

iv) Si es mayor el monto del legado, y el alimentario-legatario escoge demandar el pago de este -como hay que suponer que hará-, se aplica el artículo 1171 inciso $2^{\circ}$ CC.: en la parte coincidente, el monto se paga como baja general de la herencia (artículo 959 No 4 CC.) y grava su masa (artículo 1168 CC.); y también se aplica el artículo 1170 CC.: la parte coincidente no está sujeta a deducciones en razón de las deudas y cargas que gravaren la herencia, de modo que no contribuye al pago de las demás deudas hereditarias ni testamentarias; pero en la parte excesiva, vale como legado ordinario, es decir, su pago se imputa a la parte de libre disposición del testador y se extrae, por ende, del acervo líquido; además, ese exceso queda sujeto a la responsabilidad subsidiaria que, de acuerdo con las reglas generales, gravan a todos los legados. En fin, el exceso nuevamente pone bajo escrutinio la deuda alimenticia hacia el futuro, bajo dos respectos. Primeramente, si él permitiere juzgar que se ha modificado permanentemente la situación económica del alimentario a la luz del artículo 330 CC., entonces los alimentos podrían extinguirse o al menos rebajarse. En seguida, como lo permite el artículo 1170 CC., de todo modos pueden rebajarse los alimentos futuros si parecen desproporcionados ahora a las fuerzas del patrimonio sucesorio efectivo.

v) Si el monto del legado es menor al fijado en la sentencia o transacción, queda al arbitrio del alimentario demandar los alimentos según el legado o según el título original, en los términos del artículo 1171 inciso $2^{\circ}$ CC.; aunque, si escogió la primera opción, después podría desdecirse y demandar la diferencia según el título original, porque los alimentos son irrenunciables (artículo 334 CC.), si bien ahora podría renunciar la diferencia que en el intermedio hubiera correspondido pagar según el título original, ya que ella equivale a pensiones atrasadas y estas son renunciables (artículo 336).

53 Sobre este aspecto de un legado de lo debido, véase GUZMÁn (2006) pp. 81-82. 
9. Al comenzar, además del precedente, también dejamos otros puntos pendientes, y este es el lugar para tratarlos.

a) Uno de tales puntos atañe a los alimentos demandados a un supuesto obligado a ellos de acuerdo con algún título legal, quien falleció antes de emitirse la sentencia condenatoria o de haberse llegado a una transacción [caso iii) del número 1]. La doctrina está conforme -si bien con menos entusiasmo que en el caso de sentencia o transacción producidas en vida del alimentante- con que tales alimentos, una vez que se emita la sentencia, por cierto, o se llegue a una transacción, son de cargo de los herederos y se comportan como los debidos merced a una u otra libradas en vida del alimentante ${ }^{54}$. La razón es que, de acuerdo con el artículo 331 CC., los alimentos se deben desde (la notificación de) la demanda, o sea, desde la de la primera demanda, en el entendido que después haya sentencia condenatoria; de guisa que si el demandado murió antes de la sentencia y la que con posterioridad se pronuncie contra los herederos es condenatoria, resulta que los alimentos constituidos por aquella se empezaron a deber cuando el testador vivía, al serle notificada la demanda, y alcanzaron por ello a trasmitirse a los dichos herederos. Se trata no de otra cosa que del efecto fijador de toda demanda judicial notificada, uno de cuyos contenidos es precisamente hacer transmisible un vínculo hasta entonces intransmisible.

En realidad, el punto no ofrece mayores dificultades en relación con la materia que nos ha venido ocupando; pero es preciso llevarlo expresamente al centro de la doctrina que aquí hemos sustentado.

Los alimentos constituidos por sentencia judicial emitida contra los herederos después de la muerte del demandado a título de alimentario, por lo dicho precedentemente, de deberse desde la notificación de la demanda, son tan deudas hereditarias como la de alimentos constituidos por sentencia emitida en vida del demandado. No son, pues, deudas nacidas después de su muerte, en cabeza de los herederos, que no están pasivamente afectados por el título legal que afectaba al causante.

En consecuencia, todo lo dicho para los alimentos constituidos en vida del causante por sentencia o transacción es aplicable también a aquellos constituidos por sentencia emitida en juicio iniciado contra el alimentante que murió durante su curso y afectó, por ende, a sus herederos, o por transacción entre estos y el demandante de los alimentos.

b) Otro de los puntos dejados pendientes concierne a los alimentos constituidos por sentencia o transacción en vida del alimentante, del pago de algunas de cuyas mesadas o mensualidades este se encontraba en mora al fallecer [caso i) del número 1]. La opinión común de la doctrina es que la obligación a estas mensualidades constituye sin más una deuda hereditaria que debe pagarse a título de baja general de la herencia, pero de acuerdo con lo prescrito por el artículo 959 No 2 CC. ${ }^{55}$. Ahora bien, que es

\footnotetext{
54 SOMARRIVA (2005) II, No 439, p. 364: “Este caso es menos claro que el anterior [...]”; DomínGUEZ y DOMÍNGUEZ (1998) No 891, p. 904: "Es admisible comprender también [...]”; ElORRIAGA (2005) No 454, p. 383: “También parece no caber dudas [...]”. Sin reticencias: Rodríguez (2002) I, p. 290. No se pronuncia MEZA (2007) No 407, p.101.

55 Domínguez y Domínguez (1998) II, No 891, pp. 903-904; Rodríguez (2002) I, p. 287; ElorriAGA (2005) No 453, pp. 381-382. No se pronuncia MEZA (2007) No 407, p.101.
} 
deuda, que es hereditaria y que es baja general, no cabe duda; pero no debemos considerarla baja del No 2 sino del No 4. Ello es consecuencia lógica de lo que hemos venido sosteniendo. Una vez que se ha reconocido que los alimentos forzosos son, todos ellos y en sí mismos, deudas hereditarias que se pagan como baja general según el No 4 del artículo 959 CC., no se ve por qué las mensualidades que el alimentante tenía atrasadas al morir no han de seguir el mismo destino en cuanto a bajas. Pero se entiende que la doctrina dominante piense como se ha expuesto precedentemente: porque no ha tenido en cuenta el carácter de deuda hereditaria de todos los alimentos forzosos; y siendo ostensible ese carácter con respecto a las mensualidades atrasadas, resultaba natural adscribir su pago al No 2. Aceptada la tesis que hemos expuesto aquí, la solución contraria se impone.

10. Todavía hay otro punto, que dejamos pendiente.

a) Se trata de aquel de un testador que, sin haber sido constituido en deudor de alimentos por sentencia o transacción libradas durante su vida, los pagaba voluntariamente entonces, en reconocimiento, empero, de haber título legal para exigirlos por parte del alimentario [caso iv) del número 1]: una vez fallecido tal alimentante, ¿deja obligados a sus herederos? En opinión de Claro Solar ${ }^{56}$, seguida por Somarriva ${ }^{57}$ y, de paso, por Domínguez y Domínguez ${ }^{58}$, los deja obligados, y tales alimentos se sustancian igual que los constituidos por sentencia o transacción producidas en vida del alimentante; últimamente se ha pensado lo contrario ${ }^{59}$.

En nuestra opinión, el asunto debe ser planteado como pasamos a explicar:

Un acuerdo (por la naturaleza de la situación siempre lo habrá) entre cierta persona, como alimentante, y otra, o quien la represente, como alimentario, en orden a dar alimentos la primera a la segunda, por existir un título legal para pedirlos de parte de esta última, es una transacción extrajudicial sobre alimentos futuros, que al menos precave un litigio eventual (artículo 2446 CC.) ${ }^{60}$. Ahora bien, para valer una transacción sobre alimentos futuros, ella requiere aprobación judicial (artículo 2451 CC.). Si la hubo, se genera el caso normal de alimentos debidos que se trasmiten a los herederos, según todo lo dicho en este trabajo. Si no la hubo, no vale $y$, en consecuencia, no se trasmiten a ellos.

b) Aún podemos enriquecer más la hipótesis y suponer la de un testador que, sin previamente haber debido alimentos por haber sido constituidos mediante sentencia o transacción judicialmente aprobada, libradas durante su vida, ni sin al menos haber sido

56 Claro (1942) XV, 1, No 182, pp. 166-167.

57 SOMARRIVA (2005) II, No 439, pp. 363-364.

58 DomíngueZ y Domínguez (1998) II, No 891, pp. 903-905, no se proponen directamente el punto; pero, en p. 904, dicen, en efecto, obiter: "[...] los alimentos respecto de los cuales hay declaración judicial o reconocimiento voluntario del alimentante, han de seguirse pagando como asignación forzosa por la masa hereditaria".

59 RodrígueZ (2002) I, pp. 289-290; Elorriaga (2005) No 554, pp. 383.

$60 \mathrm{Si}$ los alimentos fueron pedidos o exigidos al supuesto sujeto pasivo del título para pedirlos, y este accede a pagarlos en determinadas condiciones, no parece caber dudas que se trata de una transacción. Pero puede prestarse a dudas el hecho de que, sin previa petición o exigencia, alguien, sobre la base de 
demandado de alimentos entonces, no los lega sino que reconoce deberlos en su testamento y ordena su pago. Tales alimentos reconocidos, ¿obligan a los herederos?

Esta hipótesis es un caso especial de la prevista por el artículo 1133 CC.: "Las deudas confesadas en el testamento y de que por otra parte no hubiere un principio de prueba por escrito, se tendrán por legados gratuitos y estarán sujetos a las mismas responsabilidades y deducciones que los otros legados de esta clase”. Se observará que esta norma nada dice acerca de la naturaleza y del valor de la confesión testamentaria de deudas que se encuentra apoyada en un principio de prueba por escrito. No es, por cierto, el momento de tratar tal figura. Limitémonos a decir que la existencia o inexistencia del principio de prueba por escrito referido por el artículo 1133 CC. solo tiene por función decidir si una confesión testamentaria de deudas es verdaderamente tal o si, por conversión, es un legado ordinario (o "gratuito" como lo llama ese artículo). Aquí nos circunscribiremos al caso en que no haya principio de prueba por escrito. Entonces la confesión de deber el testador alimentos forzosos se convierte en un legado gratuito, o sea, voluntario de alimentos, de aquellos regulados por los artículos 1134 y 1171 inciso $1^{\circ} \mathrm{CC}$. En consecuencia, esos alimentos constituyen, no deuda hereditaria, sino deuda testamentaria, no son baja general de la herencia y están sujetos subsidiariamente a las deducciones y contribuciones a que está sujeta la generalidad de los legados. Con estas advertencias, la respuesta a la pregunta inicial de si la confesión testamentaria de deberse alimentos obliga a los herederos es positiva, pero los obliga a título de legado ordinario.

11. Con lo anterior damos por ultimado el examen dogmático de la asignación forzosa de alimentos debidos por ley a ciertas personas, del cual concluimos que tal asignación, en realidad, no existe, o, para ser más exactos, que la regulación legal de una asignación así llamada y considerada es una construcción inane de la ley. Lo verdaderamente sustantivo de esta son sus artículos 959 No 4, 1168 y 1170 segunda parte del Código Civil, sobre la base de reconocerse la naturaleza de deuda hereditaria que tienen los alimentos constituidos entre vivos por medio de una sentencia, aunque sea emitida después de fallecido el demandado durante su vida, o una transacción. Si eso es así, en el silencio del testador, los alimentos debidos de la manera dicha gravan la herencia, aunque no el patrimonio personal de los herederos, y se pagan como baja del No 4; y lo mismo se hace si aquel los asigna mediante un legado. De asignación forzosa, pues, no cabe hablar.

\footnotetext{
haber tal título, los ofrezca y los pague al supuesto alimentario (que acaso ignora la existencia del título o no ha pensado en hacerlo valer), porque haría defecto una controversia actual, que el acuerdo soluciona, precaviendo un litigio eventual. El que se ofreció como alimentante actúa tal vez movido por su conciencia y en función de cumplir un deber legal, que además considera moral. Pero si se tiene presente que también pudo ser movido por la consideración de un eventual juicio de alimentos, que desea evitar, o por pagar alimentos en menor cuantía que aquella a la que eventualmente puede ser condenado, atendida la situación patrimonial del alimentario y la suya, nos obliga a prescindir de todos los posibles estados de ánimo del que ofrece pagar alimentos, sean altruistas o egoístas aquellos, que nos conduciría a distinciones improcedentes en Derecho, y a permanecer en el hecho objetivo de que cualquier acuerdo sobre pago de alimentos siempre es una transacción.
} 
Pero falta aún por saber la razón de que el Código utilice el lenguaje impropio de asignación forzosa con respecto a esta especial deuda hereditaria que son los alimentos forzosos.

Se trata de un relicto legislativo, como pasamos a ver.

a) El libro De la sucesión por causa de muerte del "Proyecto de 1841-1845", en el artículo 1 No 3 de su título 8º, consideraba asignación forzosa a "los legados de alimentos para ciertas personas", y ella venía desarrollada en un $₫ 3$ de ese mismo título, bajo la rúbrica: De las asignaciones alimenticias que se deben a ciertas personas, dotado con un nada escaso articulado ${ }^{61}$. Esto último se explica como corolario de que el libro De la sucesión por causa de muerte fue el primero del futuro Código en ser compuesto, de modo que a su tiempo aún no existía ni en bosquejo el futuro libro De las personas, en donde la mayoría de las normas del $\$ 3$ del título $8^{\circ}$, antes citado, hubieran encontrado su lugar natural. Seguramente por esa razón Bello se sintió inducido a tratar sobre varios aspectos de los alimentos forzosos en ese $\$ 3$ a través de artículos que después, al ser compuesto el libro sobre las personas, debieron emigrar a él ${ }^{62}$, como son: el elenco de individuos a quienes se deben alimento (artículo 40 del título 8º), la cuantía de los alimentos (artículo 41 inciso $1^{\circ}$ ), quiénes los deben en el caso especial del ex religioso o exclaustrado (artículo 42), duración de la deuda de alimentos al ex religioso o exclaustrado y a otras personas (artículo 43).

Este limitado horizonte de los alimentos forzosos en el proyecto permite entender que su perspectiva fuera la de un legado de alimentos, que quien por ley los debe queda

61 En BELlo (1887) XI, pp. 99-101.

62 Este fenómeno de la historia de la codificación civil chilena, de que en los primeros proyectos cierta materia apareciera tratada en sede impropia, para solo después, en los proyectos finales, fuera fijada en su lugar apropiado, se repitió en otros casos. Por ejemplo, en el título 7o: De varias especies de asignaciones, del libro De la sucesión por causa de muerte, del "Proyecto de 1841-1845", se contiene un $\$$ 1: De la asignación de usufructo [en BELLO (1887) XI, pp. 55-58]. El usufructo, por ende, va considerado como asignación testamentaria especial. Toda esa materia, si bien con mucho desarrollo, pasó al título 9o: Del derecho de usufructo, localizado en el libro II: De los bienes, y de su dominio posesión uso y goce, del "Proyecto de 1853" [en Bello (1888) XII, pp. 205-216] y después, por cierto, al título 9o del mismo libro del Código. En estas nuevas sedes tan solo se recuerda que, entre otros modos, el usufructo se constituye "por testamento", o sea, por legado (artículo 766 No 2 CC.). Otro ejemplo: en el $\$ 3$ del título 22: De la venta, del libro De los contratos y obligaciones convencionales del "Proyecto de 1841-1845", Bello reguló las maneras de hacerse la tradición (artículo 20), considerada como obligación del vendedor [en BELLO (1887) XI: pp. 228-229]. Las normas ahí expuestas pasaron a formar parte de los artículos 822 a 825 del "Proyecto de 1853 ", sitos en su libro II: De los bienes, y de su dominio posesión uso y goce, dentro del título 6०: De la tradición [en BELlO (1888) XII, pp. 184-185], y conservaron esta localización en el Código (artículo 684). Y hay más ejemplos. Este fenómeno se explica bien si suponemos que el autor de los proyectos del Código no preveía la totalidad de este, en grado de abstenerse de regular figuras que en el cuerpo completo habrían de ocupar su lugar natural, como si solo el proyecto parcial fuere el que iría a ser promulgado; y a fin de que la parte promulgada no contuviere vacíos, procedía entonces a estas regulaciones inorgánicas. Ahora bien, esta suposición es concordante con la idea sustentada por Bello durante un tiempo, en orden a que la codificación chilena debería emprenderse por partes y no en el todo, como finalmente acaeció. Tal idea fue expuesta por Bello en algunos escritos publicados hacia fines de la década de 1830; pero seguramente la concibió antes. Para todo, véase: GUZMÁn (1981), Congreso, II, pp. 188-193. El mismo, en Revista de Estudios Histórico-Jurídicos (1981), pp. 295-302. Véase también: GUZMÁN (1982) I, pp. 278-283. 
constreñido a disponer en su testamento a favor de aquel a quien los debe, como si la satisfacción del deber empezara al morir el deudor ${ }^{63}$. Tales alimentos debían ser pagados con cargo a los bienes sucesorios: el artículo 44 del $\$ 3$ en examen, en efecto, ordenaba que la asignación alimenticia al ex religioso y al que hizo una donación cuantiosa al difunto se dedujeran del "cuerpo de bienes", inmediatamente después de las deudas hereditarias y de las expensas para la apertura de la sucesión; y que las mismas asignaciones a los descendientes y ascendientes se dedujeran de la "cuota de bienes de que el difunto pudo disponer a su arbitrio". Por otro parte, su artículo 41 inciso $3^{\circ}$ prescribía que si los alimentos asignados por el difunto fueren insuficientes, se aumentaran hasta la que pareciere justa, habida consideración a varias circunstancias y, en primer lugar, a "las fuerzas del patrimonio" sucesorio. Quedaba, así, claro que la asignación forzosa de alimentos debía ser sustentada por la herencia. La posibilidad de que los herederos tuvieran que llegar a sustentarla con su propio patrimonio era del todo ajena al proyecto. Se trataba, pues, de una auténtica y pura asignación hereditaria.

Los sucesivos proyectos jamás lograron deshacerse de esta idea inicial, aunque variaron la naturaleza de la asignación.

b) El libro De la sucesión por causa de muerte del "Proyecto de 1846-1847", en el cual proyecto tampoco aparece otro sobre las personas, trata de nuestra materia en sus artículos 178 a $182^{64}$. Sin perjuicio de conservar las disposiciones del precedente, varió de un modo insospechado sus supuestos, cuando añadió la idea de que la obligación de pagar los alimentos "recae sobre los herederos y legatarios a prorrata de sus emolumentos" (artículo 182 inciso $2^{\circ}$ ). Con ello dio entrada a la idea de que los alimentos forzosos son deudas del difunto que se heredan, y a tal punto, que es menester a los herederos afrontarlas incluso con recursos propios, no ganados en la sucesión de que se trate, aunque a prorrata del emolumento sí ganado en ella (igual, por lo demás, que en el caso de todas las deudas hereditarias, como dice el artículo 320 inciso $2^{\circ}$ del mismo proyecto). Claro es que el citado artículo 182 añadía inmediatamente: "pero habida siempre consideración al estado de su fortuna" (de los herederos y legatarios), lo cual, junto con corroborar la responsabilidad personal, concedía un beneficio que la limitaba.

El inciso $2^{\circ}$ del artículo 182 era, sin embargo, un cuerpo extraño en el articulado, que seguía discurriendo sobre la base de ser los alimentos una asignación hereditaria que grava el patrimonio sucesorio y que repercute sobre los herederos solo en cuanto lo grava (porque entonces reciben menos emolumento). En efecto, el mentado inciso sigue al $1^{\circ}$ del artículo 182, que correspondía al artículo 44 del $\$ 3$ del título $8^{\circ}$ del libro sobre

\footnotetext{
${ }^{63}$ De todas maneras, debemos advertir no haber sido que estuviera absolutamente ausente en el proyecto la suposición de una obligación previa del alimentante, ya entre vivos, que, por ende, podría venir siendo cumplida por aquel desde antes de morir. En efecto, el artículo 43 del título $8^{\circ}$ del $\$ 3$, que analizamos, establecía que los alimentos se deben al religioso exclaustrado "desde el momento de su exclaustración"; y a los descendientes y ascendiente y al donante, "desde el momento en que se hallaren necesitados”, y, por cierto, esos momentos pueden llegar ya en vida del obligado a prestar los alimentos. Mas era una norma aislada, como constitutiva de cierta excepción en un articulado cuyo sistema discurre generalmente sobre la base de una asignación de alimentos por causa de muerte.

${ }^{64}$ Bello (1887) XI pp. 357-359.
} 
sucesiones del "Proyecto de 1841-1845", con modificaciones dice: "Las asignaciones alimenticias gravan directamente a la cuota de bienes que el difunto pudo disponer a su arbitrio, y subsidiariamente a todo el caudal hereditario" 65 . Así que esta disposición mudó su sentido original. En el "Proyecto de 1841-1845" servía para denotar que es la herencia (no interesa ahora qué parte de ella), y solo ella, la que paga los alimentos. Ahora solo significó que los paga, pero no con exclusividad, porque, como añadió el inciso $2^{\circ}$, los herederos deberían afrontar la deuda en caso de no existir bienes en la herencia. El inciso $1^{\circ}$, pues, mira el asunto desde el punto de vista de los herederos, quienes normalmente pagarán los alimentos con los bienes de la herencia; pero el inciso $2^{\circ}$ lo miraba desde el punto de vista de los alimentarios quienes demandarán a los herederos para que paguen, no importa si con bienes de la herencia (y normalmente así será, si los hay) o con bienes propios (normalmente cuando no los haya). Pero esto es así cuando no se quiera ver una contradicción entre ambos inciso del artículo 182.

c) El "Proyecto de 1853", en cambio, ya incluyó un libro I: De las personas, cuyo título $18^{\circ}$ trata De los alimentos que se deben por ley a ciertas personas ${ }^{66}$, concebidos, por cierto, como debidos ya entre vivos.

Según era de esperarse, el contenido de varias disposiciones sobre alimentos que antes estaban situadas en el párrafo relativo a los alimentos forzosos del libro sobre sucesiones pasó al mentado título $18^{\circ}$ del libro sobre personas, de modo de mermarse el articulado del $\$ 1$ del título $5^{\circ}$ del libro III sobre sucesiones del nuevo "Proyecto de 1853", que es el departamento correspondiente de aquellos de los proyectos anteriores que trataban de la asignación forzosa de alimentos.

El "Proyecto de 1853" reformuló la nueva idea introducida por el inciso $2^{\circ}$ del artículo 182 del precedente. Su artículo 371, ahora con la perspectiva de que los alimentos se empiezan a deber entre vivos, establecía: "La obligación de prestar alimentos se trasmite a los herederos y legatarios del que ha debido prestarlos", si bien nada dijo sobre la prorrata con la que responde cada sucesor, como sí lo decía el mentado inciso $2^{\circ}$; y sin referencia al estado de la fortuna de cada sucesor. Dejando a un lado el punto de si esta norma concernía solo a los alimentos forzosos ya declarados por sentencia o transacción, o también a los no declarados así, por no haber sido reclamados en vida del supuesto alimentante, bastando para nuestro actual tema considerar únicamente la primera hipótesis, es claro que con dicha norma se venía a decir que, una vez fallecido el alimentante, sus herederos (y legatarios) lo sucedían en la deuda de alimentos que aquel había tenido durante su vida, de guisa que ahora aquellos continuaban sujetos a su cumplimiento. Pese a su silencio sobre la prorrata, podemos interpretar que implícitamente decía el artículo 1329, además, que esa obligación seguía la regla general de las obligaciones transmisibles, a saber, que se divide entre los herederos según sus cuotas (y los legatarios

\footnotetext{
${ }^{65}$ En el proyecto anterior, como vimos, se distinguía entre las asignaciones alimenticias del ex religioso y del donante, por un lado, que se deducían del cuerpo de bienes, y las de los ascendientes y descendiente, por otro, que se deducían de la cuota de libre disposición. Ahora todas sin distinción se deducen de esta; aunque se añadió la idea de que el resto es gravado subsidiariamente.

66 BeLlo (1888) XII pp. 312-313.
} 
según su emolumento). En consonancia con todo lo anterior, el artículo 1329 del mismo "Proyecto de 1853", pero sito en el libro III, estableció: "Los asignatarios de alimentos serán considerados como acreedores del difunto; pero este crédito no tendrá lugar en perjuicio de los demás acreedores hereditarios".

Resulta claro entonces que la perspectiva completa del derecho de alimentos, que empieza entre vivos y se mantiene después de la muerte del alimentante, permitió a Bello calar en su verdadera naturaleza de deuda hereditaria ${ }^{67}$. Pero ello no fue suficiente para liberar al proyecto de la rutina de los precedentes, que consideraban una asignación forzosa de alimentos por causa de muerte; y en vez de eliminar esta del libro sobre sucesiones, se la mantuvo, pese a la inconsistencia que implicaba su conservación, una vez reconocida la naturaleza de deuda hereditaria de los alimentos. Un claro relicto fue la conservación del criterio contenido en el artículo 41 inciso $3^{\circ}$ del libro sobre sucesiones del "Proyecto de 1846-1847" en el artículo 1328 del de 1853, aunque ahora atañó, no al aumento, sino a la rebaja para el futuro de los alimentos, cuando aparecen "desproporcionados a las fuerza del patrimonio efectivo". Este criterio, totalmente congruente cuando se considera a los alimentos como objeto de una asignación que debe ser soportada por la herencia y solo por ella, es incongruente con la idea de unos alimentos que son objeto de cierta obligación que debe ser soportada por los herederos, incluso con su propio patrimonio.

d) El carácter de deuda hereditaria también fue admitido en el "Proyecto Inédito" 68 -responsable de nuevas mermas a la regulación sobre los alimentos forzosos aplicadas al "Proyecto de 1853"-, cuyo artículo 1325 dijo: "La obligación de prestar alimentos no se transmite a los herederos sino a favor de las personas designadas" en ciertos números del artículo 360, que, en el libro sobre personas del mismo proyecto, señala a los titulares, ya entre vivos, de alimentos forzosos. Para el "Proyecto Inédito", pues, también se trataba de una obligación transmisible, aunque de él fue eliminado el artículo 1329 del "Proyecto de 1853", mas no por otras razones que estas: i) la idea contenida en la primera parte del artículo 1329 del "Proyecto de 1853" ("Los asignatarios-difunto") quedó incorporada en el nuevo artículo 1325, que se acaba de citar; y ii) su segunda parte ("pero este crédito-hereditarios") quedó reflejado en un también nuevo artículo $1116 \mathrm{~b}$ del "Proyecto Inédito", que implantó la noción que denominamos "bajas generales de la herencia”, inexistente en los anteriores, pues entre ellas aparecieron, como después en el Código (con otra denominación), las "asignaciones alimenticias forzosas" en su No 5, lo cual equivalía a decir que la deuda de alimentos "no tendrá lugar en perjuicio de los demás acreedores hereditarios", cuyos créditos aparecían mencionados en el No 1 del mismo artículo 1116b. El "Proyecto Inédito" mantuvo la norma del artículo 1328 del anterior, con su mismo número en este, en orden a rebajar los alimentos futuros desproporcionados a las fuerzas del patrimonio efectivo, que seguía siendo incongruente con al naturaleza de deuda de los herederos reconocida a los alimentos forzosos.

\footnotetext{
${ }^{67}$ Se observará que el recién citado artículo 1329 habla del crédito alimenticio y lo compara con los "otros acreedores hereditarios".

${ }^{68}$ BELLO (1890) XIII pp. 300-301.
} 
e) En otra revisión del Proyecto de Código Civil (de 1853) posterior a aquella que dio lugar al "Proyecto Inédito" y anterior a la publicación del "Proyecto de 1855", que fue el presentado al Congreso Nacional y aprobado como Código Civil, se introdujo, en sustitución del antes citado artículo 1325 del dicho "Proyecto Inédito", el actual artículo 1168: "Los alimentos que el difunto ha debido por ley a ciertas personas, gravan la masa hereditaria; menos cuando el testador haya impuesto esa obligación a uno o más participes de la sucesión", que, en efecto, ya aparece en el mentado "Proyecto de 1855 "69. La nueva disposición parece ser consonante con el carácter de baja general dado a los alimentos forzosos ya en el "Proyecto Inédito", aunque no sea consecuencia directa de ser baja ${ }^{70}$. Pero no destaca por su claridad ${ }^{71}$. Si lo que quiso establecer fue que los alimentos forzosos resultaren soportados por la masa hereditaria y solo por ella, vale decir, sin una eventual contribución complementaria del patrimonio de los herederos, lo dijo mal, porque se echa de menos un adverbio como "solamente", "únicamente", "exclusivamente", u otras expresiones equivalente, conectados con "gravan”. Este proyecto mantuvo, en su artículo 1170, la norma sobre rebaja de alimentos desproporcionados a las fuerzas del patrimonio efectivo, que ahora, atendido lo malamente dispuesto por su nuevo artículo 1168, ya no resultó incongruente, porque es lógico que si solo la herencia financia los alimentos forzosos, ese financiamiento pueda ser limitado a sus fuerzas efectivas. Esta reforma implicó volver a la idea original del "Proyecto de 1841-1845"; pero no en forma pura, por ahora, a diferencia de lo que acaecía en aquel, resultaba claro que los alimentos forzosos, pese a todo, seguían siendo deudas hereditarias. En el resto, el "Proyecto de 1855", vale decir, prácticamente el Código, no dejó de mermar otra vez el articulado de los alimentos forzosos, dejándolo reducido a cuatro disposiciones, que, sin menoscabo de especie alguna, bien pudieron ser relocalizados en otros departamentos del Código en donde encuentran sede natural.

f) La historia legislativa que acabamos de considerar nos revela, pues, que los alimentos emergieron en la codificación bajo la forma de una asignación por causa de muerte, que, por consiguiente, debía ser soportada por la herencia, tal cual aparece configurada en el "Proyecto de 1841-1845". Esa construcción fue secuela de la ausencia de un horizonte legal más amplio, que los adelantara como figura entre vivos, cuya sede natural debía ser la parte del Código (o de su proyecto) destinada a tratar el Derecho de las personas, para que solo subsiguientemente fueran retomados como figuras por causa de muerte, debido a que a la sazón del tratado sobre sucesiones, el primero en ser emprendido, por lo mismo aún no existía aquel sobre personas. En el "Proyecto de 1846-1847” se conservó los lineamientos esenciales de la asignación, pero se le superpuso la idea distorsionadora de que los alimentos forzosos son deudas del difunto que recaen sobre los herederos a prorrata de sus emolumentos. En el "Proyecto de 1853", en

\footnotetext{
69 Proyecto de Código Civil (1855), p. 307.

${ }^{70}$ Como se ve a través del caso de las deudas hereditarias, que siendo también bajas generales, no gravan toda la herencia, sino a cada heredero a prorrata de sus asignaciones: véase la nota 30 .

71 Véase el número 5, b).
} 
el cual ya existe un libro sobre personas, que contiene la figura de los alimentos entre vivos, y en su revisión que condujo al "Proyecto Inédito", quedó reafirmado el carácter de deuda hereditaria que ofrecen los alimentos; y ahora lo distorsionador fue que, por una suerte de rutina legislativa, no se diera el paso complementario de eliminar la antigua asignación por causa de muerte de alimentos. Y así esta quedó en el "Proyecto de 1855" y en el Código, en los cuales al retornarse a la idea original de que los alimentos son soportados solo por la herencia y nunca el patrimonio de los herederos, se reafirmó su naturaleza de asignación hereditaria forzosa, sin sustraerle la de deuda hereditaria. Con ello, la materia adquirió definitivamente su doble naturaleza de asignación hereditaria y deuda hereditaria; o, si se prefiere, y es mejor en realidad, de deuda hereditaria con rasgos de asignación hereditaria; o sea, de un auténtico injerto que da origen a un monstruo.

La asignación forzosa de alimentos es, en verdad, un fantasma legal inconsistente, cuya idea esencial de mantener aun contra la voluntad del testador los alimentos a quienes los recibían en vida del alimentante, se satisface por sí misma, atendida su verdadera naturaleza de deuda hereditaria, que no necesita ser ni siquiera mencionada por el testador y que se paga con o sin su voluntad; no por ser asignación forzosa, sino precisamente por ser deuda hereditaria.

\section{BIBLIOGRAFÍA CITADA}

Alfonso, Paulino (1882): Explicaciones de Código Civil destinadas a los estudiantes del ramo en la Universidad de Chile (Santiago, Imprenta Cervantes).

AgUirRe VARGAS, Carlos (1891): "Las asignaciones alimenticias forzosas y la porción conyugal”, en: AGUIRRE VARGAS, Carlos, Obras jurídicas (Santiago, Imprenta Gutenberg) $464 \mathrm{pp}$.

Bello, Andrés (1887): Obras completas de don [...] (Santiago, Pedro G. Ramírez) XI: Proyectos de Código Civil.

Bello, Andrés (1888): Obras completas de don [...] (Santiago, Pedro G. Ramírez) XII: Proyecto de Código Civil (1853).

Bello, Andrés (1890): Obras completas de don [...] (Santiago, Pedro G. Ramírez) XIII: Proyecto Inédito de Código Civil.

Claro Solar, Luis (1942): Explicaciones de Derecho civil chileno y comparado, XV: De la sucesión por causa de muerte (1942, reimpresión Santiago, Editorial Jurídica de Chile, 1992, VII).

Claro Solar, Luis (1943): Explicaciones de Derecho civil chileno y comparado, III: De las personas (1943, reimpresión Santiago, Editorial Jurídica de Chile, 1992, II).

Domínguez Benavente, Ramón y Domínguez ÁGuila, Ramón (1998): Derecho sucesorio (2a edición, Santiago, Editorial Jurídica de Chile, 1998).

Elorriaga DE BONIS, Fabián (2005): Derecho sucesorio (Santiago de Chile, LexisNexis) $778 \mathrm{pp}$.

GuZMÁn Brito, Alejandro (1981): "Para la historia de la fijación del Derecho civil en Chile durante la república, IX: El pensamiento de Bello sobre codificación del Dere- 
cho", en: Bello y Chile. Tercer congreso del bicentenario (Caracas, La Casa de Bello, 1981), II, Revista de Estudios Histórico-Jurídicos No 6 (Valparaíso, 1981).

GUZMÁn BRITO, Alejandro (1982): Andrés Bello codificador. Historia de la fijación y codificación del Derecho civil en Chile (Santiago, Ediciones de la Universidad de Chile) I.

GUZMÁN BRITO, Alejandro (2006): "La tipología de los legados en el Derecho civil chileno", Revista de Derecho de la Pontificia Universidad Católica de Valparaíso No 27, Semestre I: pp. 81-82.

MEZA BARros, Ramón (2007): Manual de la sucesión por causa de muerte y de las donaciones entre vivos ( $8^{a}$ edición, Santiago, Editorial Jurídica de Chile) 535 pp.

Proyecto de Código Civil (1855): (Santiago, Imprenta Nacional)

Rodríguez GREZ, Pablo (2002): Instituciones de Derecho sucesorio (2a edición, Santiago de Chile, Editorial Jurídica de Chile) 403 pp.

Somarriva Undurraga, Manuel (2005): Derecho sucesorio (6a edición, Santiago, Editorial Jurídica de Chile).

VodAnOvic, Antonio (2004): Derecho de alimentos (40 edición, Santiago, LexisNexis) 286 pp. 
